\title{
A study on the level of stress and the influence of socio-demographic factors on stress level among the working women in the state of Kerala
}

\author{
Harilal.A ${ }^{1}$ \\ Researcher- Bharathiar University \\ E-mail: harilal10@gmail.com \\ Santhosh V A ${ }^{2}$ \\ TKM Institute of Management \\ E-mail: drsanthoshva@gmail.com
}

\begin{abstract}
Women play vital roles in the process of decision making both in work place and family. Indian culture considers women as care takers of the family members. In contrary to the traditional notions, women are moving from home maker's par name to working women. More number of women is entering into workforce that is very much challenging and innovative. Aforementioned state gives a double role to most of the women as working women and house wives without any interval. Here a study is undertaken on the level of stress of women who are in the dual standards of family and profession. The study tries to identify the stressful life faced by women in the society. The result indicates that financial position of the family, travelling time and mode of travelling affect the intensity of stress among the working women. It provides us an opportunity to give suggestions to women in facing and challenging critical situations of their lives effectively.
\end{abstract}

Keywords: Stress, Working women, Socio-demographic

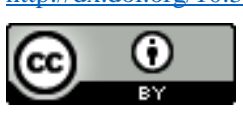

OPEN 2 ACCESS

2523-6547 - Copyright: (C) 2017 The Authors. This is an open access article distributed under the terms of the Creative Commons Attribution License, which permits unrestricted use, distribution, and reproduction in any medium, provided the original author and source are credited. 


\section{INTRODUCTION}

The main duties of women include running or managing families, bringing up and educating the children, cooking and storing food, buying goods, cleaning and maintaining homes, making clothes for the family etc. An ironical thing is that a woman employed inside the home is referred to as 'housewife' and outside the framework of house as 'working woman'. In both situations the woman is working, but, the difference in naming is based on the working place in which she belongs to. A woman who earns salary, wages, or other income through employment, outside home, is termed as working woman. As part of globalization, the employment environment is changing all over the world. Now the literacy rate among women is increasing and it ensures increasing participation of women in organizations. In India also, the status of man as the head of the family is changing.

1. Research scholar, Bharathiar university,Coimbatore,Tamilnadu,harilal10@gmail.com

2. Dean \& Professor (Operations), TIM,Kollam,Kerala,drsanthoshva@gmail.com

The women are getting educated and they are in very large number moving towards working environment. Working inside and outside the house are the two life phases of a woman. Balancing the work and family roles has become a major issue for women. The stress a woman suffers to maintain balance between her duties both in home and workplace should be taken into account. The researcher's intention gets relevance in this contemporary scenario.

\section{LITERATURE REVIEW}

The concept of stress was introduced in the life science by Selye Hans in 1936. Stress is defined as a real or perceived imbalance between environmental demands required for survival of a person and an individual's capacity to adapt to these requirements (Lazarus and Folkman, 1984). It is an external event or internal drive which threatens to upset the organic equilibrium (Selye Hans, 1956), causing threat to the quality of work life as well as physical and psychological well-being (Cox, 1978). Stress is determined as generalised, patterned unconscious mobilization of the body's natural ability (Yahaya et al., 2009). Stress is a consequence of or a general response to an action or a situation that place special physical or psychological demands or both on a person (Hogan, 1991). Job stress is considered as "a condition arising from the interaction of people and their jobs and characterized by changes within people that force them to deviate from their normal functioning" (Beehr and New man, 1978). There are two types of stressors, namely, psychosocial and biogenic. Psychosocial stressors occur when a person reacts to an event or a situation or a stimulus based on the attributed perception of that stressor as a threat and biogenic stressor occurs when body react $s$ to caffeine or environmental conditions such as temperature.

More number of women are entering into workforce and facing two different environments, i.e.family environment and working environment, with multiple roles and conflicting expectation (Nelson, D. L. and Bruke R. J., 2000). The job related stressors are adverse working conditions, such as excessive noise, extreme temperature or overcrowding (Mcgrath, 1978), role ambiguities, conflict, overload and under load (Arcold et al, 1986).). Explored stress management techniques used by working women are sleep and relaxation, exercise, time management, diet and yoga (Upamany (1997). The Research reports that supportive work and family policy, effective management communication, health insurance coverage for mental illness and chemical dependence and fixed scheduling of work hours were effective in reducing job burnout (Lawless, 1991). Work and family are two important part of a person's life and both are closely related (Ford et al., 2007). More and more numbers of women are entering the work force and pursuing careers (Sevim., 2006) where they have to balance the competing demand of both work place and family life (Bickasiz,2009). Working women are doing their job for longer hours and taking more work at home during night (Dawn et al, 1999). This creating more pressure is putting on working women. But the real fact that exists about mental stress is that it is unable to measure in meaningful and valid scale equivalent to kilocalorie per minute in terms of utility and formal measurement properties (Kantowitz, B.H., \& Casper, P.A, 1988).

\section{OBJECTIVE AND METHODOLOGY OF THE STUDY}

The main objective of the study, which is descriptive in nature, is to identify the level of stress among working women in the state of Kerala. The study also explores the relationship of demographic factors like age, education, financial position, daily travelling time, mode of travelling, work time, employment status, and employment status of husband on the level of stress experienced by working women in the state of Kerala. The targeted population consists of working women in the state of Kerala. The responses are collected from Thiruvananthapuram,

2523-6547 - Copyright: (C) 2017 The Authors. This is an open access article distributed under the terms of the Creative Commons Attribution License, which permits unrestricted use, distribution, and reproduction in any medium, provided the original author and source are credited. 
Ernakulam and Kozhikode districts. Data were collected from 90 respondents, 30 from each district. Probability sampling method was used to collect data from each district. General role stress scale is used in this study. It is a self administered questionnaire having a respondent rate of 12 items on a 5 point scale. GRSS is highly related to psychometrically established ORS and its cronbach's alpha reliability coefficient is .733 over 12 items.

\section{HYPOTHESIS OF STUDY}

$\mathrm{H}_{1} 1^{-} \quad$ There is a significant relationship between stress level of working women and age.

$\mathrm{H}_{2^{-}} \quad$ There is a significant relationship between stress level of working women and education.

$\mathrm{H}_{3^{-}}$There is a significant relationship between stress level of working women and nature of employment of husband.

$\mathrm{H1}_{4^{-}} \quad$ There is a significant relationship between stress level of working women and financial position.

$\mathrm{H}_{5^{-}} \quad$ There is a significant relationship in stress level of working women having house maid.

${\mathrm{H} 16^{-}}^{-} \quad$ There is a significant relationship between stress level of working women and daily travelling time.

$\mathrm{H}_{7^{-}} \quad$ There is a significant relationship between stress level of working women and work time

${\mathrm{H} 18^{-}}^{-} \quad$ There is a significant difference between stress level of working women and mode of travelling. 


\section{FINDINGS AND DISCUSSION}

\section{Demographic profile}

Ninety Working women of thirty, each from Thiruvananthapuram, Ernakulam and Kozhikode took part in this study. Working women with SSLC (14.4\%), plus two (17.80), graduation (34.4\%), and post graduation (33.3\%) participated in the study. $8.9 \%$ of working women belongs to upper middle class, $85.6 \%$ to middle class and 5.6 $\%$ to lower middle class. About employment status of husband of working women $34.4 \%$ are working in the government sector and $45.6 \%$ in the Private sector. $17.8 \%$ are self-employed and $2.2 \%$ are not employed. (Table No: 1$)$.

Demographics

Table No: 1

\begin{tabular}{|c|c|c|c|}
\hline & District & \multicolumn{2}{|c|}{ Working women } \\
\hline Sl No & & Frequency & Percent \\
\hline 1 & Thiruvananthapuram & 30 & 33.3 \\
\hline 2 & Ernakulam & 30 & 33.3 \\
\hline \multirow[t]{2}{*}{3} & Kozhikode & 30 & 33.3 \\
\hline & Total & 90 & 100.0 \\
\hline Sl No & Education & & \\
\hline 1 & SSLC & 13 & 14.4 \\
\hline 2 & Plus two & 16 & 17.8 \\
\hline 3 & Degree & 31 & 34.4 \\
\hline \multirow[t]{2}{*}{4} & Post graduation & 30 & 33.3 \\
\hline & Total & 90 & 100.0 \\
\hline Sl No & Financial Position & & \\
\hline 1 & Upper middle class & 8 & 8.9 \\
\hline 2 & Middle class & 77 & 85.6 \\
\hline \multirow[t]{2}{*}{3} & Lower middle class & 5 & 5.6 \\
\hline & Total & 90 & 100.0 \\
\hline Sl No & Employment status of Husband & & \\
\hline
\end{tabular}

2523-6547 - Copyright: (C) 2017 The Authors. This is an open access article distributed under the terms of the Creative Commons Attribution License, which permits unrestricted use, distribution, and reproduction in any medium, provided the original author and source are credited. 


\begin{tabular}{|l|l|l|l|}
\hline 1 & Government & 31 & 34.4 \\
\hline 2 & Private & 41 & 45.6 \\
\hline 3 & Self employed & 16 & 17.8 \\
\hline 4 & Not employed & 2 & 2.2 \\
\hline & Total & 90 & 100.0 \\
\hline
\end{tabular}

Stress level of working women with a mean value of 27.1667 (SD, 6.5105) clearly states that the working women in Kerala are facing more stress. When compared, various factors of Stress are also relatively high for working women (6.5667). Stress arising due to inter-role distance is also significantly high for working women (7.3556). Regarding role boundedness the mean value of working women is 7.3556. The Mean value with respect to Stress arising due to personal adequacy comes to 7.0000 and for self role distance comes to 6.56 for working women. The analysis shows inter- role distance and role boundedness of working women is high (Table No, 2).

Analysis of stress among working women

Table No: 2

\begin{tabular}{|c|c|c|c|c|c|}
\hline & \multicolumn{5}{|c|}{ Working women } \\
\hline & Min & Max & Sum & Mean & Std.dev \\
\hline Total stress & 13 & 50 & 2445 & 27.16 & 6.5105 \\
\hline Self role distance stress & 3 & 14 & 591 & 6.56 & 2.0611 \\
\hline Inter role distance stress & 3 & 14 & 662 & 7.35 & 2.5847 \\
\hline Role boundedness stress & 3 & 14 & 662 & 7.35 & 2.5847 \\
\hline Personal inadequacy stress & 3 & 12 & 630 & 7.00 & 2.1305 \\
\hline
\end{tabular}

The correlation done between stress of working women and age gives a mean score of 27.1667 and Pearson correlation value (r) of -.150 and significance value is .158 (P>.05). The p value shows that age and stress of working women doesn't have significant relationship. The analysis also clearly indicates the same trend on the factors of stress and age among working women. With respect to self role distance the mean value is $6.5667, \mathrm{r}$ value is -.071 and significance value is $.506(\mathrm{P}>.05)$. Regarding inter-role distance the mean value is 7.3556 , Pearson correlation value is -.180 and significant value is .090 ( $>>.05)$. The mean value of stress due to role boundedness is 7.3556. Pearson correlation between role boundedness of working women and age is -.1800 and significance value is $.090(\mathrm{P}>.05)$ which shows that age and stress due to role boundedness doesn't have significant relationship. The analysis shows that relationship between stress due to personal inadequacy and age is 7.00 with an $r$ value of -.177 and significant value of .096 ( $\mathrm{P}>.05$ ) indicating a weak relationship (Table No, 3) 
Analysis of age and stress of working women

Table No: 3

\begin{tabular}{|c|c|c|}
\hline \multirow{2}{*}{ Total Stress } & Stress and Age & \\
and Age & Pearson Correlation & -.150 \\
& Sig. (2-tailed) & .158 \\
N & 90 \\
\hline \multirow{2}{*}{ Self-role distance } & Pearson Correlation & -.071 \\
and Age & Sig. (2-tailed) & .506 \\
Nnter role distance & $\mathrm{N}$ & 90 \\
and Age & Pearson Correlation & -.180 \\
& Sig. (2-tailed) & .090 \\
Role boundedness and & $\mathrm{N}$ & 90 \\
Age & Pearson Correlation & -.180 \\
& Sig. (2-tailed) & .090 \\
Personal inadequacy and & $\mathrm{N}$ & 90 \\
\hline Age & Pearson Correlation & -.177 \\
& Sig. (2-tailed) & .096 \\
\hline
\end{tabular}

The ANOVA analysis between education and stress of working women gives an F-value of 1.575 and a significance value is $.201(\mathrm{P}>.05)$. The $\mathrm{p}$ value shows that education and stress is having no significant relationship with respect to working women. Even if the relationship is not statistically significant, the stress of working women with degree as their qualification is high followed by Post graduation, plus-two and SSLC. (Table No, 4)

Analysis between education and stress of working women

Table No: 4

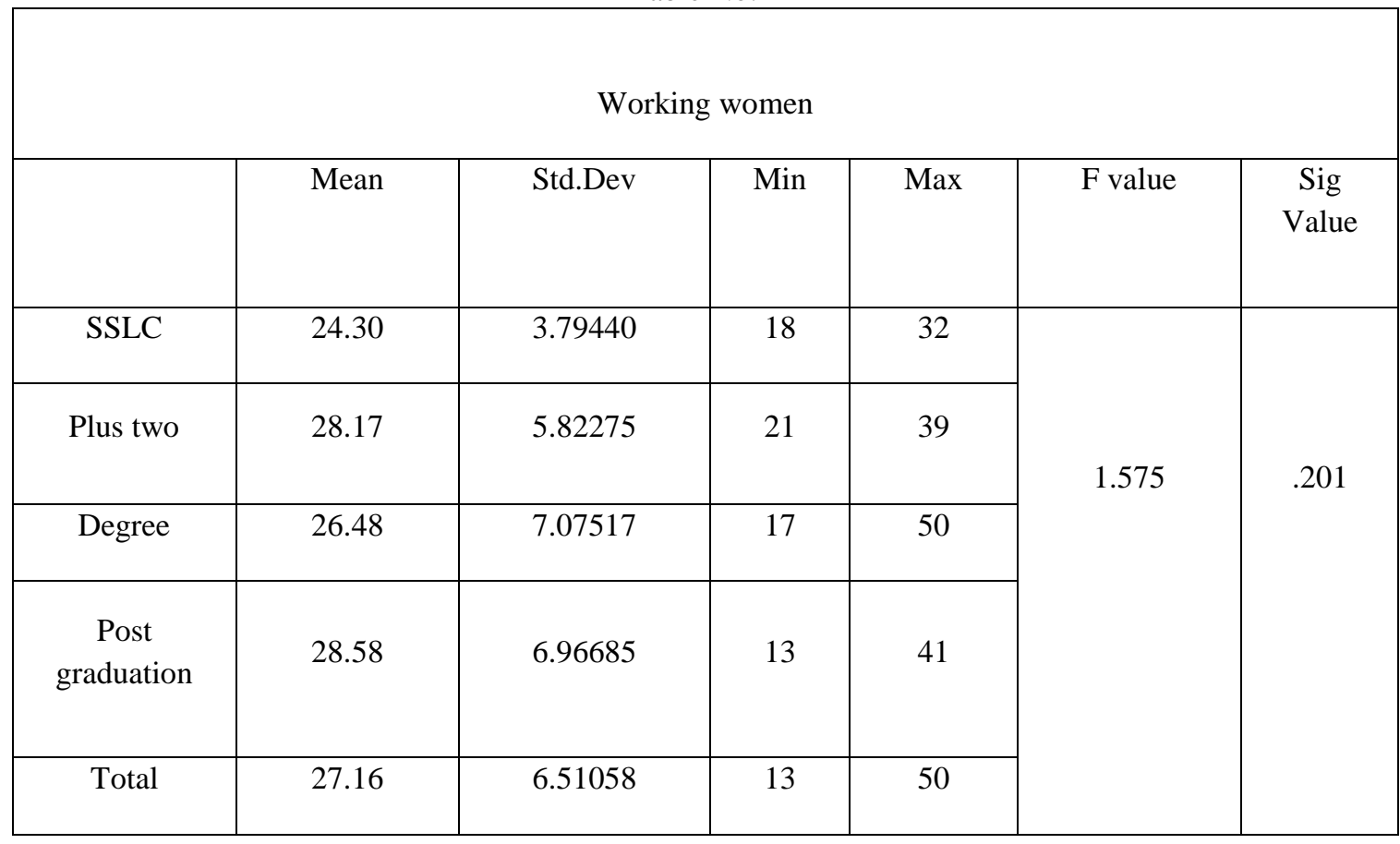

2523-6547 - Copyright: (C) 2017 The Authors. This is an open access article distributed under the terms of the Creative Commons Attribution License, which permits unrestricted use, distribution, and reproduction in any medium, provided the original author and source are credited. 
The analysis that is made to understand the influence of employment status of husbands and stress level of working women shows an F-value of .852 and a significant value of .462 (P>.05). The p value shows that there no significant relationship between stress of working women and employment status of husband. (Table No, 5)

Analysis between employment status of husband with Stress.

Table No: 5

Working women

\begin{tabular}{|c|c|c|c|c|c|c|}
\hline & Mean & Std.Dev & Min & Max & F value & Sig Value \\
\hline Government & 27.16 & 7.5148 & 13 & 50 & & \\
\hline Private & 27.21 & 6.2270 & 17 & 41 & \\
\hline Self employed & 26.18 & 5.2690 & 19 & 38 & \\
\hline Not employed & 34.00 & 1.4142 & 33 & 35 & \\
\hline Total & 27.16 & 6.5105 & 13 & 50 & & \\
\end{tabular}

Stress is high for the lower middle class working women when compared with the upper middle class and middle class. ANOVA analysis between financial position of working women and their stress gives an F-value of 4.008 and significance value is $.002(\mathrm{P}<.05)$. The $\mathrm{P}$ value indicates that there is a significant relationship between financial position of working women and their stress. (Table No, 6)

Analysis between financial position and stress of working women

Table No: 6

Working women

\begin{tabular}{|c|c|c|c|c|c|c|}
\hline & Mean & Std.Dev & Min & Max & F value & Sig Value \\
\hline $\begin{array}{c}\text { Upper } \\
\text { middle class }\end{array}$ & 29.00 & 6.5900 & 22 & 39 & 4.008 & .022 \\
\hline Middle class & 26.46 & 6.3612 & 13 & 50 & & \\
\hline
\end{tabular}

2523-6547 - Copyright: (C) 2017 The Authors. This is an open access article distributed under the terms of the Creative Commons Attribution License, which permits unrestricted use, distribution, and reproduction in any medium, provided the original author and source are credited. 


\begin{tabular}{|c|c|c|c|c|c|c|}
\hline $\begin{array}{c}\text { Lower } \\
\text { middle class }\end{array}$ & 33.66 & 4.8027 & 26 & 39 & \multirow{2}{*}{} & \\
\hline Total & 27.16 & 6.5105 & 13 & 50 & & \\
\hline
\end{tabular}

Stress is higher for working women who have no house maids. The t-test between working women who are having and not having house maid and its impact on level of stress show a value of .985 and a significance value of .324 ( $\mathrm{P}>$.05). The $\mathrm{P}$ value indicates that even with high stress level for working women who have no house maid, the difference is not significant when compared with those who have house maid. (Table No: 7)

Having house maid and stress

Table No: 7

\begin{tabular}{|c|c|c|c|c|}
\hline & \multicolumn{3}{|c|}{ Working women } \\
\hline Stress & Mean & Std. Dev & t value & \multicolumn{2}{|c|}{ Sig Value } \\
& & & & \\
\hline House Maid & 26.61 & 8.7420 & & \\
& & & & \\
\hline No House Maid & 27.25 & 6.1245 & & \\
\hline
\end{tabular}

The correlation between daily travelling time and stress is .387 and significance value is $.000(\mathrm{P}<.05)$. The $\mathrm{P}$ value shows that there is a significant relationship between stress and daily travelling time of working women. The positive value of Pearson correlation says that, there is a positive relationship between daily travelling time and stress. If the particular employ travels less distance per day, it also alleviates her stress (Table No: 8)

Daily travelling time and stress

Table No: 8

\begin{tabular}{|c|c|c|c|}
\hline \multicolumn{3}{|c|}{ Working women } \\
\hline \multicolumn{2}{|c|}{} & Travelling time & Stress \\
\hline \multirow{2}{*}{$\begin{array}{c}\text { Travelling } \\
\text { time }\end{array}$} & Pearson Correlation & 1 & $.387^{* *}$ \\
& Sig. (2-tailed) & & .000 \\
N & Pearson Correlation & 90 & 90 \\
\hline \multirow{3}{*}{ Stress } & Sig. (2-tailed) & .387 & 1 \\
& N & .000 & 90 \\
\hline
\end{tabular}

2523-6547 - Copyright: (C) 2017 The Authors. This is an open access article distributed under the terms of the Creative Commons Attribution License, which permits unrestricted use, distribution, and reproduction in any medium, provided the original author and source are credited. 
The mean stress of women working in general shift and those working in other shifts is similar. The t-test analysis shows that $\mathrm{F}$-value is .002 and significance value is .962 (P>.05). The $\mathrm{P}$ value shows that there is no significant relationship between stress and working time. (Table No: 9 )

Work time and stress

Table No: 9

\begin{tabular}{|c|c|c|c|c|}
\hline \multirow{2}{*}{ Work Time } & \multicolumn{3}{|c|}{ Stress } \\
& \multicolumn{3}{|c|}{ Sig value } \\
\hline & Mean & Std.Dev & t value & . \\
\hline General & 27.14 & 6.5147 & & .962 \\
\hline Shift & 27.42 & 6.9727 & & .002 \\
\hline
\end{tabular}

Stress is higher for women who use public transport when compared with those who use own vehicle for daily travelling to working place. ANOVA analysis gives F-value of 3.699 and significance value is .029 $(\mathrm{P}<.05)$. The $\mathrm{P}$ value shows that there is a significant relationship between mode of travelling to office and stress of working women. (Table No: 10).

Mode of travelling and stress

Table No: 10

\begin{tabular}{|c|c|c|c|c|c|c|}
\hline \multicolumn{2}{|c|}{ Working women } \\
& Mean & Std.Dev & Min & Max & F value & $\begin{array}{r}\text { Sig } \\
\text { Value }\end{array}$ \\
\hline Public transport & 28.13 & 6.4968 & 17 & 50 & & \\
\hline Company vehicle & 26.83 & 6.1779 & 22 & 39 & \multirow{2}{*}{3.699} & .029 \\
\hline Own vehicle & 23.47 & 5.5914 & 13 & 36 & & \\
\hline Total & 27.16 & 6.5105 & 13 & 50 & & \\
\hline
\end{tabular}

2523-6547 - Copyright: (C) 2017 The Authors. This is an open access article distributed under the terms of the Creative Commons Attribution License, which permits unrestricted use, distribution, and reproduction in any medium, provided the original author and source are credited. 


\section{CONCLUSION}

The research examined stress among working women and the factors leading them to stressful situation. Daily travelling time, mode of travelling and financial position have relationship with the stress of working women. Stress is a part of human life; sometimes it can motivate us and help us to become more productive. Stress will increase our ability to be alert, productive, and energetic and help us in facing challenges and dangerous situations. But too much stress is harmful for us. This stress will lead us to tense, anxious, fatigued, burnout situations. It would be better, if we are equipped with the knowledge of managing stress with the help of various techniques. This study extends its scope by bestowing insights to the working women to understand the nature and level of their stress. This study also will be help for life partners and organisations to understand the level of stress among their counter parts. This research also ensures credibility and objectivity and so can be treated as a base for future studies in the same and related fields. 


\section{Reference}

Arnold, H. J., and Feldman. (1986). Organizational Behaviour. New York: McGraw Hill.

Bickazsiz .P., (2009). The effect of Gender role ideology role salience, role demands and core self evaluation on work-family interface. M.Sc Thesis. Middle East University Technical University.

Beehr, T.A. and New Man, S.E (1978) . Job Stress, employee health and organizational effectiveness: Facet analysis, Personnel Psychology, winter, pp $665-669$.

Cox,T.,(1978), Stress, New York; McMillan

Dawn S.Carlson and Pamela L.Perrewe , (1999). "The role of social support in the Stressor-Strain Relationship: An examination of Work Family Conflict,” Journal of Management,Vol.25, No.4, pp.513-540.

Ford, M.T, B.A. Heinen and K.L.Langkarner, (2007).Work and family Satisfaction and Conflict; A meta analysis of cross-domain relation. Journal of Applied Psychology ., 92:57-80.

Hogan,R. ,(1991).Personality and personality measurement.In M.D.Dunnettee and L.M.Hough(2eds) . "Hand book of industrial and organisational psychology". Palo Aito, Calif Consulting psychologist press. Vol.3.2, pp 571-650.

Lawless, P. ,1991. Employee Burnout: America's Newest Epidemic. Minneapolis, MN: North western National Life Employee Benefits Division.

McGrath, J. E. (1976). "Stress and behaviour in organizations." In Handbook of Industrial and Organizational Psychology. Dunnett, M. D. (ed) Chicago: Rand McNally College Publishing 1341-1396.

Selye,H.,(1956),The stress of Life, New York; Mc. Graw Hill

Sevim, S.A. ,(2006). Religious tendency and gender roles: Predictors of the attitudes toward womens work roles. Soc. Behav. Personal . Intl. J. 34: 77- 86.

Upamanyu,K.,(1997),Stress Management in Educated Women.Indian.J.Soc.Res,38(3):185-189.

Yahaya, A, N. Yahaya, K. Arshad, J. Ismail and S. Jaalam et al.,(2009).Occupational stress and its effects towards the organisation Management.J.Soc.Sci.,5:390-397

Nelson, D. L. and Bruke R. J. (2000). Women Executive Health, Stress and Success. The Acadamey of Management Executive, 14, 107-21.

Lazarus, R. S., \& Folkman, S. (1984). Stress, appraisal, and coping. New York: Springer

Everly, G. S., \& Lating, J. M. (2002). A clinical guide to the treatment of the human stress response (2nd ed.). New York: Kluwer Academic.

Kantowitz, B.H., \& Casper, P.A. (1988). Human workload in aviation. In E. Wiener \& D. Nagel (Eds.), Human factors in aviation (p. 164). New York: Academic Press.

2523-6547 - Copyright: (C) 2017 The Authors. This is an open access article distributed under the terms of the Creative Commons Attribution License, which permits unrestricted use, distribution, and reproduction in any medium, provided the original author and source are credited. 
2523-6547 - Copyright: (C) 2017 The Authors. This is an open access article distributed under the terms of the Creative Commons Attribution License, which permits unrestricted use, distribution, and reproduction in any medium, provided the original author and source are credited. 